www.volsu.ru

DOI: https://doi.org/10.15688/nsr.jvolsu.2019.1.2

UDC 664-035.66

LBC 65.305.73-31

\title{
COMPARATIVE ANALYSIS OF THE MARKET OF FOOD SUPPLEMENTS IN RUSSIA, USA AND CHINA
}

\author{
Mikhail P. Lyabin \\ Volgograd State University, Volgograd, Russian Federation \\ Margarita V. Postnova \\ Volgograd State University, Volgograd, Russian Federation \\ Alexey I. Bolkunov \\ Volgograd State University, Volgograd, Russian Federation
}

\begin{abstract}
This article is devoted to theoretical research of the market of food additives in Russia, the USA and China. The concept of food additives, their features, as well as aspects of the development and market conditions of food additives, such countries as Russia, China and the United States. The concepts of food ingredients and food stabilizers are specified. The use of micro-credits for the production of the main groups of food products is revealed. It shows the location of the largest markets for food additives in the countries studied, and describes in detail the benefits of importing food additives. Answers are found to the questions why domestic producers of food ingredients, in many cases, can not compete with foreign firms either in the nomenclature or in terms of production of a larger number of classes of food additives; and how the raw material category contributes to the optimization of production technology. The reasons complicating this competition are specified. The event, which became a "marker" for the food additives industry in 2014, is mentioned. Official definitions of food additives are disclosed, according to DSHEA (Law on health and education of food additives). The clarification is given due to what is carried out to ensure the growth of the market, and in what directions will develop Russian production in the near future.
\end{abstract}

Key words: food additives, sodium isoascorbate, flavorings, sodium citrate, potassium tartrate, regulation, sodium pyrosulfate, cost minimization.

УДК 664-035.66

○ ББК 65.305.73-31

\section{СРАВНИТЕЛЬНЫЙ АНАЛИЗ СОСТОЯНИЯ РЫНКА ПИЩЕВЫХ ДОБАВОК РОССИИ, США И КИТАЯ}

\author{
Михаил Павлович Лябин
}

Волгоградский государственный университет, г. Волгоград, Российская Федерация

\section{Маргарита Викторовна Постнова}

Волгоградский государственный университет, г. Волгоград, Российская Федерация

\section{Алексей Иванович Болкунов}

Волгоградский государственный университет, г. Волгоград, Российская Федерация

Аннотация. Данная статья посвящена теоретическому исследованию рынка пищевых добавок в России, США и Китае. Проанализированы понятие о пищевых добавках, их особенности, а также аспекты развития и состояния рынка пищевых добавок, таких стран, как России, Китая и США. Указаны понятия о пищевых 
ингредиентах и пищевых стабилизаторах. Раскрывается использование микроингредиентов для производства основных групп продуктов питания. Показано местонахождение самых больших рынков пищевых добавок в изучаемых странах, и подробно описываются преимущества импорта пищевых добавок. Найдены ответы на вопросы, почему отечественные производители пищевых ингредиентов, во многих случаях не могут конкурировать с иностранными фирмами ни по номенклатуре, ни по объемам выпуска большего числа классов пищевых добавок; и как сырьевая категория способствует оптимизации технологии производства. Указаны причины, затрудняющие данную конкуренцию. Упоминается событие, которое стало «маркерным» для отрасли пищевых добавок в 2014 году. Раскрываются официальные определения пищевых добавок, согласно DSHEA (Закон о здоровье и образовании пищевых добавок). Дано уточнение за счет чего осуществляется обеспечение роста рынка, и в каких направлениях будет развиваться российское производство в ближайшей перспективе.

Ключевые слова: пищевые добавки, изоаскорбат натрия, ароматизаторы, цитрат натрия, тартрат калия, регламентация, пиросульфат натрия, минимизации издержек.

Введение. В настоящее время в связи с расширением технологий и рынка пищевых добавок научная литература уделяет большое внимание вопросам его развития $[3 ; 7 ; 11 ; 16$; $19 ; 28 ; 30]$. Помимо этого, в России действует национальная программа и ряд законодательных актов развития биотехнологии, которая целенаправленна на налаживание производства отечественной биотехнологической продукции и сокращение импорта $[4 ; 5 ; 6 ; 12$; $13 ; 14 ; 18 ; 20 ; 21 ; 24 ; 25 ; 31]$. Актуальность темы обусловлена тем, что в настоящее время в производстве продуктов питания применяется более 500 пищевых добавок [1; 2].

Таким образом, рынок пищевых добавок является прямым отражением рынка продуктов питания. Он является катализатором рынка продуктов питания и во многом определяет развитие пищевой индустрии. Посредством применения пищевых добавок упрощается технология производства, расширяется ассортимент, повышается безопасность, привлекательный вид, вкус, пищевая ценность, полезность продуктов питания, а также улучшается их текстура и насыщенность.

Целью исследования выступал анализ состояния рынка пищевых добавок России, США и Китая на основе научно-методических изданий, статей и интернет-ресурсов с применением методов регистрации, подачи, группировки, классификации, сравнительного анализа, а так же обобщения научных материалов.

Результаты и их обсуждение. По определению многочисленных авторов, пищевыми добавками называют вещества, которые добавляют в продукты питания для повышения их безопасности, повышения длительнос- ти их хранения, сохранения или улучшения их вкуса, консистенции или внешнего вида [22; 23].

Они представляют натуральные или синтетические вещества, которые включены в пищевые продукты при подготовке к предоставлению определенных качеств, удлиняющие период хранения или ускорение технологического процесса, к ним относятся продукты питания, органические кислоты, ароматы, краски, консерванты, и т. д. [29].

Пищевые ингредиенты представляют инновационный инструмент обеспечения стабильности качества продуктов питания. Эта сырьевая категория способствует оптимизацию производственных технологий, и профессиональное применение которое способствует безопасности, а так же может действовать как гарант безопасности потребительских особенностей во время жизненного цикла пищевых продуктов.

Продовольственные стабилизаторы это процесс использования веществ в кондитерской, маслодельнеческой, пекарской и обрабатывающей отрасли, промышленности мяса для предоставления продуктам желательной формы, структуры, поддержания необходимой последовательности в течение длительного периода времени. Пищевые добавки широко применяются в пищевой промышленности, начиная от производства многих колбасных изделий, кондитерской сферы до незаконченных продуктов и напитков [8].

Добавки, содержащие несколько определенных продвижений компонентов, называют сложными, для исправления цвета продуктов, изменения их последовательности, увеличения веса товаров при извлечении дополнительной прибыли от реализации данной продукции. 
Сложные добавки в большинстве случаев представлены сухими соединениями, которые разбавляются водой, а так же содержатся в выпущенных продуктах при замачивании, или вводятся в продукцию посредством инъекций. Например, это такие стабилизаторы как изоаскорбат натрия (электронный 316), соли лимонной кислоты натрия (электронный 331), соли лимонной кислоты кальция (электронный 333), тартрата калия (электронный 336), фосфата натрия (электронный 339), фосфата калия (электронный 340), фосфата кальция (электронный 341) и другие [9].

Недавно наблюдался стабильный рост объема внутреннего рынка пищевых добавок. В 2017-2018 гг. объем внутреннего рынка пищевых ингредиентов был близок к 2,6 млрд долларов, его индикаторы составляли 3,9 млрд долларов. Однако нужно отметить, что обеспечение роста рынка данной категории товаров было выполнено главным образом за счет импорта. Поскольку отечественные производители способны дать приблизительно только около $5 \%$ от востребованности рынка при этом существует причина того, что пищевые добавки не подпадают под санкции в отличие от большинства других категорий пищевых продуктов благодаря этому, многие импортеры начали выполнять переориентацию относительно этого сектора товаров. В настоящее время главный импортер в Россию пищевых добавок, является Китай, доля его товаров равна 15,2 \% общей суммы рынка нашей страны $[9 ; 10]$.

Согласно данным Росстата, продукция сложных пищевых добавок в 2017 г. сделала 16,8 тыс. тонн, которые превысили данные на 2015 г. для 41 \%. К апрелю 2018 г. продукция сложных пищевых добавок была равна 9 тыс. тонн, которые превысили данные на 2015 г. на $9 \%[10]$.
Таким образом, в 2015-2017 гг. в продукции сложных пищевых добавок наблюдался устойчивый рост, и его индикаторы ежегодно увеличивались на 80 \% [10]. Согласно этим индикаторам, самый большой объем пищевых добавок наблюдался производителями в CFD (8,4 тыс. тонн или $50 \%$ после результатов) [10]. Далее следует SFD (4,4 тыс. тонн или 26 \%), Северо-Западный Федеральный округ (3,5 тыс. тонн или $21 \%$ и и Приволжский Федеральный округ (0,5 тыс. тонн или $3 \%)$ [9].

После анализа результатов полученных в январе - мае 2015 г., наблюдались незначительные изменения производства сложных пищевых добавок федеральными округами РФ. Так, производство пищевых добавок было начато в Южном федеральном округе (1,3 тыс. тонн или $15 \%$ после результатов января - мая 2015 г.) (табл. 1).

На Российском рынке пищевых добавок страны импорта, такие как Германия, по результатам 2014 года составляют, 11,1 тыс. тонн или $13 \%$, Украина - 10,3 тыс. тонн или $12 \%$, Польша - 9,1 тыс. тонн или $11 \%$ и Австрия 8,7 тыс. тонн или $10 \%$, Китай $-6,4$ тыс. тонн или $7 \%$, США - 4,3 тыс. тонн или $5 \%$ и Италия $-1,9$ тыс. тонн или $2 \%$. Давайте обратим внимание, что в 2017 г. импорт был увеличен российским рынком пищевых добавок из Украины (98 \%), Китая (57 \%) и Польши $(30 \%)$ [9].

Основными странами-импортерами на российский рынок пищевых добавок в стоимостном выражении являются Германия (95,2 млн долларов США или 19 \%) и США $(95,8$ млн долларов США или $19 \%$ ) (см. рис 1.).

В стоимостном выражении рост доставок импорта на российский рынок пищевых добавок из Украины (86 \%), Австрия (22\%), Китай (42\%), Италия (52\%), Польша (28\%) наблюдается [9; 12].

Объем производства комплексных пищевых добавок в федеральных округах России

\begin{tabular}{|l|c|c|c|}
\hline \multirow{2}{*}{\multicolumn{1}{|c|}{ Федераль ный округ РФ }} & \multicolumn{3}{|c|}{ Годы, тыс. тонн } \\
\cline { 2 - 4 } & 2014 & 2015 & 2017 \\
\hline Центральный федеральный округ & 1,1 & 8,4 & 4,4 \\
\hline Северо-Западный федеральный округ & 0,0 & 3,5 & 1,6 \\
\hline Южный федеральный округ & 0,0 & 0,0 & 1,3 \\
\hline Приволжский федеральный округ & 0,1 & 0,5 & 0,2 \\
\hline Сибирский федеральный округ & 1,8 & 4,4 & 1,5 \\
\hline Российская Федерация & 3,0 & 16,8 & 9,0 \\
\hline
\end{tabular}


По состоянию на 2018 г. имеется довольно узкий список пищевых добавок, которые предназначены для пиши человека, обработки, фармацевтических препаратов, косметических средств и других гражданских отраслей промышленности производимых в России. Данная группа продуктов очень зависима от импорта. Вопрос состоит в том, что по факту многие импортные пищевые ингредиенты применяются в различных отечественных товарах, которые представляют неотъемлемую часть современных продовольственных технологий. Проблема импортозамещения стоит остро в силу того что, пищевые добавки являются важными составляющими для пищевой промышленности и их применение еще зависит от многочисленных нормативных положений безопасности, а так же от особенностей продуктов питания, которые включены в потребительскую корзину населения России. В Министерстве сельского хозяйства создана и действует межведомственная рабочая группа, которая имеет полномочия по разрешению вопросов импортозамещения пищевых добавок.

Развитие производства пищевых ингредиентов в России очень трудный процесс, и его решение требует комплексного подхода, включая ряд различных задач по производству и инновационным разработкам в научной сфеpe. Производство главных продуктов питания требует использования микрокомпонентов таких как - пищевые добавки, ароматы, тех- нологическое поддерживающее их применение, физиологически функциональные компоненты и много других различных веществ. Все вопросы, связанные с безопасностью ее соблюдением, а также качеством выпуска микроингредиентов сырья и продуктов питания в России и странах EEAS, отрегулированы национальным и международным законодательством. Требования к регулированию данных юридических вопросов хранятся в Технических нормах Таможенного союза и согласованы с инструкциями ЕС и Кодексом Alimentarius. Использование пищевых добавок в России отрегулировано нормативными документами, которые прошли экспертизу в Роспотребнадзоре и научно-исследовательском институте еды. Кроме того, список пищевых добавок, которые отрегулированы Техническими нормами Таможенного союза МЕДИ TR 029/2012 для применения в производстве продуктов питания в России и странах Таможенного союза ЕАЭС, имеет 352 единицы, их без индекса «Е»-7, не включая сложные пищевые добавки, число которых постоянно растет [17].

Если сравнить Россию с США и Китаем, то в этих странах список пищевых добавок превышает российский на 500-700 наименований. В течение прошлых 25 лет в мире были значительно изменены номенклатура и производство пищевых добавок, и также география их производства. Согласно проводимым исследованиям, центр производства продовольственных микроингредиентов из Европы и Северной

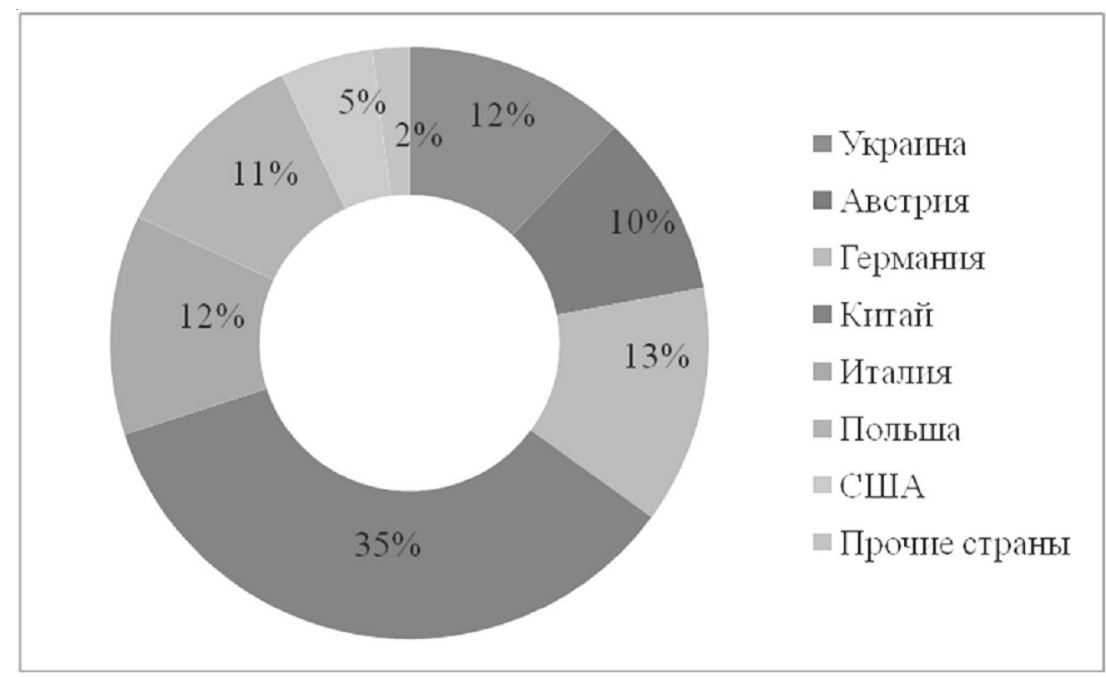

Рис. 1. Структура импорта комплексных пищевых добавок по странам производителям в 2017 г., в натуральном выражении 
Америки был перемещен в Китай. В этой стране объем этой продукции увеличивался каждый год на $10 \%$, наряду с тем, что в США он увеличивался не больше, чем на 3 \%, и в Европе - меньше, чем на $1 \%$ [23].

Китай имеет тенденцию интеграции промышленных предприятий пищевых ингредиентов и для этой страны этот факт характерен. Самые большие рынки пищевых добавок - рынки Китая и США. В 2015 г. мировой рынок ароматов был увеличен на 7 \% и профинансирован 8,7 млрд долларов, 2017 г. размер рынка вырос до 10,7 млрд долларов.

Основные потребители ароматов в мире представлены сферами экономики, касающимися производства различных напитков, и составляют $31,3 \%$, молочных продуктов и мороженого - 20,9\%, закусок и кондитерской продукцией - 13,4 \% [15].

Исследуя рынок пищевых добавок в Китайской Народной Республике, нужно отметить, что у промышленного комплекса этой страны есть необходимые ресурсы, которые способствуют эффективному улучшению их экономики. Производство пищевых добавок в этой стране составляет приблизительно $22 \%$ от всех производимых продуктов, которые выпускаются в настоящее время. Обычно предприятия этого сегмента расположены в Северных, Восточных и Центральных областях этого государства, которые выпускают наборы различных продуктов для обработки разнообразного сырья. Так, на территории Китая расположены больше чем 70000 предприятий пищевой промышленности, которые обладают высокотехнологичным оборудованием. Китай является мировым лидером в производстве пищевых добавок с различными функциями, их производством заняты 850 предприятий, которыми производятся ежегодно больше чем 20000 различных наименований концентратов. Заводы постоянно реализуют внедрение инновационных технологий, которые способствуют улучшению качества продуктов и минимизации расходов, уменьшая при этом себестоимость товаров и снижая цены для иностранных потребителей $[10 ; 17]$.

У импорта пищевых добавок из Китая есть такие преимущества, как строгий закон гигиены и безопасности, который гарантирует соблюдение всех требований производства работ с концентратами, низкая стоимость, широкая номенклатура выпускаемых пищевых добавок, которая в глобальном масштабе уже превысила 15 \%. Такие пищевые добавки как - глутамат натрия, продовольственный глицерин, продовольственные ароматы, краски, эмульгаторы стабилизаторы, продовольственный сорбат калия, натрий, лимонная кислота, пропионат кальция, молочная кислота, пирофосфат натрия, глюкоза и многие другие производятся в Китае [26].

Мировой рынок компонентов производителей продуктов питания высоко обширен 70 \% рынка составляют пять крупнейших производителей. Согласно данным RBC, Research, лидером мирового рынка питания является компания Компонентов ABF (Связанные британские продукты) их доля составляет 18,0 \% от всего мирового производства, в их состав входят такие компании как Kerry Ingredients \& Flavours - 16,5 \%, Cargill - 15,0 \%, IFF $10,5 \%$, и Danisco составляют 9,7\% США.

Производство пищевых добавок в США это быстрорастущая отрасль промышленности (рис. 2) [27].

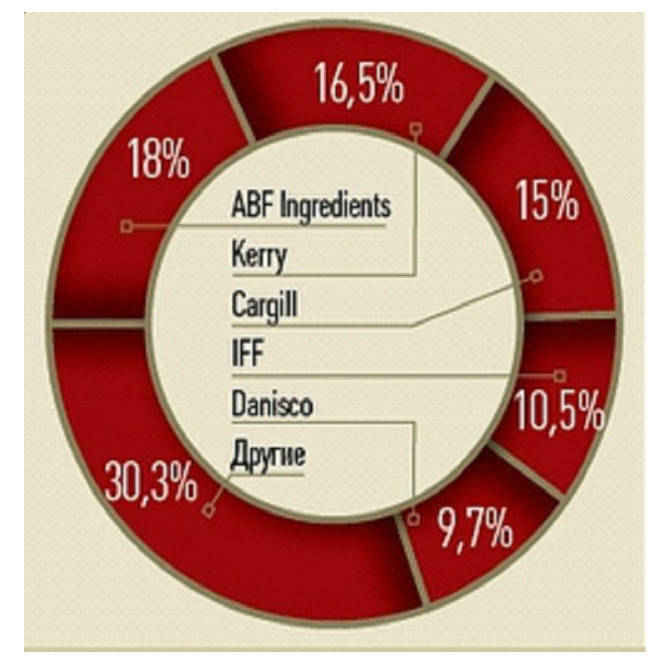

Рис. 2. Мировой рынок пищевых ингредиентов, \% [27]

Рынок ароматизаторов сконцентрирован, почти $2 / 3$ от общего объема продаж от доли четырех мировых гигантов, таких как Givaudan, IFF, Symrise и Fermtnich. Крупные мировые игроки выполняют мировой контроль этой продукции, они известны в России и продают на нашем рынке собственные продукты через дистрибьюторов. Отмечается то, 
что доля импорта микрокомпонентов, которые составляют пищевые добавки различных функциональных классов, таких как ароматы и фармакологические препараты составляют приблизительно 90 \%, по данным на 2016 г. их производство составило приблизительно 2 млрд долларов в естественном эквиваленте равное 670 тыс. тонн [27]. Согласно статистическим данным, объем импорта консервантов, антиокислителей и регуляторов кислотности составил 152 тыс. тонн; красок произвели 116 тыс. тонн; эмульгаторов, сгустителей и стабилизаторов приблизительно 82,6 тыс. тонн.

Таким образом, стоит признать, что отечественные производители пищевых добавок, во многих случаях неконкурентоспособны по сравнению с иностранными фирмами согласно номенклатуре, и объемам выпуска большего количества классов различных пищевых добавок.

Основные причины, усложняющие это неравенство, состоят в том, что:

Во-первых, производство пищевых добавок в большинстве случаев представлено только 2 направлениями, такими как - производство веществ класса Е, незначительных первичных продуктов и последующего производства функциональных смесей, производство которых основано обычно на пищевых добавках и основаниях ароматических веществ. Данный факт вызывает вопрос о локализации особенно значимых сырьевых направлениях отдельных органических и неорганических веществ.

Во-вторых, практическая потеря биотехнологического и химического производства как инструмента обработки сырья и синтеза отдельных веществ.

В-третьих, недоступность инструментов государственной поддержки на развитие данных направлений производства как в сфере пищевой, обрабатывающей промышленности так и в гражданских отраслях [10;26].

Нужно отметить, что в Российской Федерации нет никакого производства 40 наименований пищевых добавок. До 2017 г. в ограниченном производстве выпускались молочная, уксусная, ортофосфорическая кислоты, выпускался отечественный лецитин, сорбит, глицерин, гликоль пропилена, измененные крах- малы в очень узком ассортименте, цвета карамели, в-каротин, арабиногалактан, фосфат натрия, нитрит натрия, гидрокарбонат натрия, хлорид кальция и магния, пиросульфата натрия. Введение мер антисанкций в 2014 г. стало довольно показательным событием в качестве «маркера» для современной отечественной промышленности. Включение продовольственных микроингредиентов в список продуктов, которые запрещают импортировать согласно резолюции правительства Российской Федерации № 77 от 07.08.2014 составили предприятия пищевой и обрабатывающей промышленности, оказавшиеся в трудной экономической ситуации. Правительство Российской Федерации было вынуждено Резолюцией № 830 от 20.08.2014 изменить Резолюцию № 778 от 07.08.2014 и, таким образом, открыть поставку микрокомпонентов из стран, которым санкциями согласно Декрету президента России от 06.08.2014 № 560 «О применении отдельных специальных экономических мер для безопасности Российской Федерации» были причинены [22]. Такое быстрое решение вопроса, должного изменить резолюцию и разрешить поставки микрокомпонентов, способствуя пониманию роли продовольственных микроингредиентов в выпуске продуктов питания. Данное положение России на мировом рынке данных товаров послужило сигналом для необходимого развития собственной индустрии пищевых добавок. Иначе решение вопроса продовольственной безопасности страны не возможно, так как имеющееся сырье, в нашей стране мы не способны обрабатывать в полноценные пищевые и различные другие компоненты по причине отсутствия инновационных технологий. Таким образом, новые направления развития аграрного и промышленного комплекса были определены, в рамках разработанных программ поддержки производителей, правительством разработаны экономические зоны поддержки этого научно-технологического направления и созданы весомые научные проекты по производству пищевых ингредиентов в РФ.

Заключение. В настоящее время на территории РФ стремительно развивается производство пищевых добавок. Производство отечественных товаров очень зависит от импорта. Иностранные компании инвестиру- 
ют средства в производство, на Российском рынке, отечественные компании сделали большой рывок в организации собственного производства и развили довольно большое количество центров научных исследований и разработок в данном направлении. Стремление российских потребителей приобретать качественные и экологически чистые ингредиенты приводит к тому, что производители постепенно переходят на использование органического сырья и производства натуральных ингредиентов. Производство пищевых добавок стало более социально ответственным, благодаря тому, что российские производители стали не только потреблять органическое сырье, но и инвестируют средства в производство биологического разнообразия. Российское производство стремительно развивается в инновационном, инвестиционном и коллаборационном направлениях, а также в области высшего образования, в частности об этом свидетельствует тесное сотрудничество с учеными, сельхозпроизводителями и пищевыми технологами.

\section{СПИСОК ЛИТЕРАТУРЫ}

1. Андрианова, Т. Г. Экологическая безопасность продуктов питании / Т. Г. Андрианова, Н. Ю. Сысоева // Проблемы ветеринарии и ветеринарно-санитарной экспертизы и биологической безопасности : материалы междунар. науч.-практич. конф. студентов и аспирантов - М., 2015. C. $11-15$.

2. Аршкенова, А. М. Экологическая безопасность продуктов питания / А. М. Аршкенова, Д. Н. Несипкалиева // Безопасность городской среды : сб. материалов IV Междунар. науч.-практич. конф. - М., 2017. - С. 206-209.

3. Бондаренко, В. А. Рынок экологически чистых продуктов: мировой опыт и перспективы развития в России / В. А. Бондаренко, О. Н. Миргородская, Н. А. Дадаян // Инновационные достижения зеленой логистики: международный опыт и российская практика : материалы международ. науч.-практич. конф. «XIII Южно-Российский логистический форум». - Ростов н/Д : РГЭУ, 2017. - С. 119-122.

4. Воронкова, О. Ю. Формирование и развитие регионального АПК, ориентированного на производство органической (экологически чистой) продукции / О. Ю. Воронкова, Е. А. Ельчищев // Вестник алтайской науки. - 2015. - № 34 (25-26). - C. $165-170$.
5. Веренцов, Д. С. Органические продукты в России: проблемы и перспективы / Д. С. Веренцов, Р. К. Шмаков, Г. А. Толмачев // Актуальные направления научных исследований XXI века: теория и практика. - 2015. - Т. 3, № 6 (17). - С. 77-81.

6. ВП-П8-2322. Комплексная программа развития биотехнологий в Российской Федерации на период до 2020 года : утв. Правительством РФ 24.04.2012 №1853п-П8. - Электрон. текстовые. дан. - Режим доступа: https://legalacts.ru/doc/vpp8-2322-kompleksnaja-programma-razvitijabiotekhnologii-v-rossiiskoi (дата обращения: 15.02.2019). - Загл. с экрана.

7. Грешонков, А. М. Стратегические приоритеты в обеспечении экономической безопасности в продовольственной сфере / А. М. Грешонков // Экология. - 2018. - № 4. - С. 4-38.

8. Денискин, В. В. Экономические аспекты использования пищевых добавок в производстве продуктов питания / В. В. Денискин // Казанская наука. - 2012. - № 11. - С. 84-86.

9. Дмитриев, М. А. Пищевые добавки, проверенные временем / М. А. Дмитриев // Мясная индустрия. - 2014. - № 2. - С. 40-43.

10. Зеленский, В. Е. Основы развития производств пищевых добавок - стратегия качества и кадровый потенциал / В. Е. Зеленский // Пищевая промышленность. - 2011. - № 12. - С. 12-14.

11. Козонова, Ю. О. Сравнительный анализ законодательной базы использования пищевых добавок в Украине и ЕС / Ю. О. Козонова, Н. Н. Поварова // Пищевая промышленность: наука и технологии. -2015 . - Т. 9, № 2. - С. 3-7.

12. Коджегулова, Д. А. О проблемах безопасности пищевых продуктов / Д. А. Коджегулова, М. Д. Дакирова // Известия Кыргызского государственного технического университета им. И. Раззакова. - 2015. - № 3 (36). - С. 273-278.

13. Маслюкова, Е. В. Экономико-правовые механизмы обеспечения продовольственной безопасности России / Е. В. Маслюкова // Азимут научных исследований: экономика и управление. 2016. - № 4 (17). - С. 275-279.

14. Молнар, П. И. Системы безопасности пищевой продукции и стандарты на продукты питания в Европе. Методы оценки соответствия / П. И. Молнар // Пищевая промышленность. - 2008 - № 7. C. 16-23.

15. Мировой рынок пищевых ингредиентов: курс на натуральность и здоровье. - Электрон. тектовые дан. - Режим доступа: http://bfionline.ru/aviews/index.html?msg=3360 (дата обращения: 10.02.2019). - Загл. с экрана.

16. Михайлова, Е. Г. Об осведомленности и отношении потребителей к пищевым добавкам в ресурсосберегающих технологиях продукции из 
водных биологических ресурсов / Е. Г. Михайлова, М. В. Ефимова // Рыбное хозяйство. - 2016. - № 6. C. $105-108$.

17. Никифорова, Т. А. Индустрия пищевых добавок: состояние и перспективы развития. Инновационная политика / Т. А. Никифорова // Пищевая промышленность. - 2014. - № 3. - С. 8-13.

18. Небалуева, Л. А. Система менеджмента безопасности: технология разработки / Л. А. Небалуева // Методы менеджмента качества. - 2005. № 8. - С. 23-25.

19. Оленков, А. Г. Экологическая безопасность продуктов питания / А. Г Оленков, П. С.Терлеева // Здоровое питание - основа жизнедеятельности человека : сб. ст. - М., 2008. - С. 140-144.

20. Плотникова, Е. Н. Добровольные экостандарты как ориентир для экологизации отрасли / Е. Н. Плотникова // Переработка молока. 2017. - № 7 (214). - С. 58-59.

21. Почицкая, И. А. Контроль качества и безопасности пищевой продукции / И. А. Почицкая, Е. И. Александровская, Н. П. Комарова // Наука и инновации. - 2017. - Т. 5, № 171. - С. 40-41.

22. Пищевые добавки в современном мире // Ведущий Образовательный портал России - 2016. Электрон. текстовые дан. - Режим доступа: https:// infourok.ru/statya-pischevie-dobavki-v-sovrem (дата обращения: 10.02.2019). - Загл. с экрана.

23. Пищевые добавки // Всемирная организация здравоохранения. - Электрон. текстовые дан. Режим доступа: https: //www.who.int/ru/news-room/ fact-sheets/detail/food-additives (дата обращения: 10.03.2019). - Загл. с экрана.

24. Распоряжение Правительства РФ от 17.04.2012 № 559-р (ред. от 13.01.2017) «Об утверждении Стратегии развития пищевой и перерабатывающей промышленности Российской Федерации на период до 2020 года». - Электрон. текстовые дан. - Режим доступа: https://rulaws.ru/goverment/ Rasporyazhenie-Pravitelstva-RF-ot-17.04.2012-N-559r (дата обращения: 15.03.2019). - Загл. с экрана.

25. Решение Комиссии Таможенного союза от 09.12.2011 № 880 (ред. от 10.06.2014 г.) «О принятии технического регламента Таможенного союза “О безопасности пищевой продукции”» (вместе с «ТР ТС 021/2011. Технический регламент Таможенного союза. “О безопасности пищевой продукции”»). - Электрон. текстовые дан. - Режим доступа: http://docs.cntd.ru/document/902320560 (дата обращения: 15.03.2019). - Загл. с экрана.

26. Ризаев, Р. М. Анализ рынка биологически активных добавок / Р. М. Ризаев, С. А. Скляренко, М. О. Стригина // Молодой ученый. - 2014. № 3 (62). - С. 516-517.

27. Сапатовски, С. О. История, современность и перспективы развития рынка пищевых стабили- заторов в России / С. О. Сапатовски // Биоэкономика и экобиополитика. - 2016. - № 1. - С. 155-158.

28. Строганов, А. О. Анализ места России на мировом рынке пищевых добавок / А. О. Строганов // Вестник ВГУЭиС. - 2015. - № 4. - С. 155-164.

29. Толстова, Е. Г. Сертификация системы менеджмента качества как гарантия безопасности продуктов питания / Е. Г. Толстова // APRIORI. Серия: Естественные и технические науки. - 2014. - № 4. - С. 9.

30. Чимонина, И. В. Экологическая безопасность продуктов питания / И. В. Чимонина, С. А. Петросян / Проблемы организации товароснабжения населения: товароведение, экспертиза, технологии производства и продвижения : сб. материалов I Междунар. науч.-практич. конф. - Новосибирск, 2013. - C. 84-89.

31. Янькова, А. Д. Система законодательства в области обеспечения качества и безопасности продуктов питания в России / А. Д. Янькова, О. Г. Филимонова // Инновационные технологии в науке и образовании : сб. ст. победителей III Междунар. науч.практич. конф. - М., 2017. - С. 111-113.

\section{REFERENCES}

1. Andrianova T.G., Sysoeva N.Ju. Jekologicheskaja bezopasnost produktov pitanii. Problemy veterinarii $i$ veterinarno-sanitarnoj jekspertizy i biologicheskoj bezopasnosti : materyaly mezhdunar. nauch.-praktich. konf. studentov $i$ aspirantov. Moscow, 2015, pp. 11-15.

2. Arshkenova A.M., Nesipkalieva D.N. Jekologicheskaja bezopasnost produktov pitanija. Bezopasnost gorodskoj sredy : sb. materialov IV Mezhdunar. nauch.-prakt. konf. Moscow, 2017, pp. 206-209.

3. Bondarenko V.A., Mirgorodskaja O.N, Dadajan N.A. Rynok jekologicheski chistyh produktov: mirovoj opyt i perspektivy razvitija v Rossii. Innovacionnye dostizhenija zelenoj logistiki: mezhdunarodnyj opyt $i$ rossijskaja praktika : materialy mezhdunar. nauch.-praktich. konf. «XIII Juzhno-Rossijskij logisticheskij forum». Rostov-onDon, RGJeU, 2017, pp. 119-122.

4. Voronkova O.Ju., Elichishhev E.A. Formirovanie i razvitie regionalnogo APK, orientirovannogo na proizvodstvo organicheskoj (jekologicheski chistoj) produkcii [Formation and development of the regional agroindustrial complex focused on production of organic (environmentally friendly) production]. Vestnik altajskoj nauki, 2015, no. 3-4 (25-26), pp. 165-170.

5. Verencov D.S., Shmakov R.K., Tolmachev G.A. Organicheskie produkty v Rossii: problemy i perspektivy [Organic products in Russia: problems 
and prospects]. Aktualnye napravlenija nauchnyh issledovanij XXI veka: teorija i praktika, 2015, vol. 3, no. 6(17), pp. 77-81.

6. VP-P8-2322. Kompleksnaja programma razvitija biotehnologij $v$ Rossijskoj Federacii na period do 2020 goda : utv. Pravitelstvom RF 24.04.2012 g. №1853p-P8). URL: https://legalacts.ru/ doc/vp-p8-2322-kompleksnaja-programma-razvitijabiotekhnologii-v-rossiiskoi (accessed January 15, 2019).

7. Greshonkov A.M. Strategicheskie prioritety v obespechenii jekonomicheskoj bezopasnosti v prodovol'stvennoj sfere [Strategic priorities in ensuring economic security in the food sector]. Jekologija [Ecology], 2018, no. 4, pp. 4-38.

8. Deniskin V.V. Jekonomicheskie aspekty ispol'zovanija pishhevyh dobavok v proizvodstve produktov pitanija [Economic aspects of the use of food additives in food production]. Kazanskaja nauka, 2012, no. 11, pp. 84-86.

9. Dmitriev M.A. Pishhevye dobavki, proverennye vremenem [Time-tested food supplements]. Mjasnaja industrija [Meat Industry], 2014, no. 2, pp. 40-43.

10. Zelenskij V.E. Osnovy razvitija proizvodstv pishhevyh dobavok - strategija kachestva i kadrovyj potencial [Bases of development of production of food additives-strategy of quality and personnel potential]. Pishhevaja promyshlennost [Food Industry], 2011, no. 12, pp. 12-14.

11.Kozonova, Ju.O. Povarova N.N. Sravnitel'nyj analiz zakonodatel'noj bazy ispol'zovanija pishhevyh dobavok v Ukraine i ES [Comparative analysis of the legislative framework for the use of food additives in Ukraine and the EU]. Pishhevaja promyshlennost: nauka i tehnologii [Food Industry: Science and Technology], 2015, vol. 9, no. 2, pp. 3-7.

12. Kodzhegulova D.A., Dakirova M.D. O problemah bezopasnosti pishhevyh produktov [On food safety issues]. Izvestija Kyrgyzskogo gosudarstvennogo tehnicheskogo universiteta im. I.Razzakova, 2015, no. 3 (36), pp. 273-278.

13. Masljukova E.V. Jekonomiko-pravovye mehanizmy obespechenija prodovol'stvennoj bezopasnosti Rossii [Economic and legal mechanisms to ensure food security in Russia]. Azimut nauchnyh issledovanij: jekonomika i upravlenie, 2016, no. 4 (17), pp. 275-279.

14. Molnar P. I. Sistemy bezopasnosti pishhevoj produkcii i standarty na produkty pitanija v Evrope. Metody ocenki sootvetstvija [Food safety systems and food standards in Europe. Conformity assessment methods]. Pishhevaja promyshlennost [Food Industry], 2008, no. 7, pp. 16-23.

15. Mirovoj rynok pishhevyh ingredientov: kurs na naturalnost i zdorovye. URL: http://bfionline.ru/aviews/index.html?msg=3360 (accessed January 10, 2019).
16. Mihajlova E.G., Efimova M.V. Ob osvedomlennosti i otnoshenii potrebitelej k pishhevym dobavkam v resursosberegajushhih tehnologijah produkcii iz vodnyh biologicheskih resursov [About awareness and the relation of consumers to food additives in resource-saving technologies of production from water biological resources]. Rybnoe hozjajstvo [Fisheries], 2016, no. 6, pp. 105-108.

17. Nikiforova T.A. Industrija pishhevyh dobavok: sostojanie i perspektivy razvitija. Innovacionnaja politika [Food additives industry: state and prospects of development. Innovation policy]. Pishhevaja promyshlennost [Food Industry], 2014, no. 3, pp. 8-13.

18. Nebalueva L.A. Sistema menedzhmenta bezopasnosti: tehnologija razrabotki [Safety management system: development technology]. Metody menedzhmenta kachestva [Methods of Quality Management], 2005, no. 8, pp. 23-25.

19. Olenkov A.G., Terleeva P.S. Jekologicheskaja bezopasnost produktov pitanija. Zdorovoe pitanie osnova zhiznedejatel'nosti cheloveka : sb. statej. Moscow, 2008, pp. 140-144.

20. Plotnikova E.N. Dobrovol'nye jekostandarty kak orientir dlja jekologizacii otrasli [Voluntary environmental standards as a benchmark for the greening of the industry]. Pererabotka moloka [Milk Processing], 2017, no. 7 (214), pp. 58-59.

21. Pochickaja I.A., Aleksandrovskaja E.I., Komarova N.P. Kontrol kachestva i bezopasnosti pishhevoj produkcii [Quality control and food safety]. Nauka i innovacii [The Science and Innovations], 2017, vol. 5, no. 171, pp. 40-41.

22. Pishhevye dobavki v sovremennom mire. Vedushhij Obrazovatelnyj portal Rossii. 2016. URL: https://infourok.ru/statya-pischevie-dobavki-vsovrem (accessed January 10, 2019).

23. Pishhevye dobavki.Vsemirnaja organizacija zdravoohranenija. URL: https://www.who.int/ru/ news-room/fact-sheets/detail/food-additives (accessed March 10, 2019).

24. Rasporjazhenie Pravitelstva RF ot 17.04.2012 № 559-r (red. ot 13.01.2017) «Ob utverzhdenii Strategii razvitija pishhevoj $i$ pererabatyvajushhej promyshlennosti Rossijskoj Federacii na period do 2020 goda». URL: https://rulaws.ru/goverment/ Rasporyazhenie-Pravitelstva-RF-ot-17.04.2012-N-559-r (accessed March 15, 2019).

25. Reshenie Komissii Tamozhennogo sojuza ot 09.12 .2011 № 880 (red. ot 10.06.2014 g.) «O prinjatii tehnicheskogo reglamenta Tamozhennogo sojuza "O bezopasnosti pishhevoj produkcii» (vmeste s "TR TS 021/2011. Tehnicheskij reglament Tamozhennogo sojuza. «O bezopasnosti pishhevoj produkcii»). URL: http://docs.cntd.ru/document/902320560 (accessed March 15, 2019) 
26. Rizaev R.M., Skljarenko S.A., Strigina M.O. Analiz rynka biologicheski aktivnyh dobavok [Market analysis of dietary supplements]. Molodoj uchenyj, 2014, no. 3 (62), pp. 516-517.

27. Sapatovski, S.O. Istorija, sovremennost i perspektivy razvitija rynka pishhevyh stabilizatorov v Rossii [History, present and prospects of food stabilizers market development in Russia]. Biojekonomika i jekobiopolitika, 2016, no. 1, pp. $155-158$.

28. Stroganov A.O. Analiz mesta Rossii na mirovom rynke pishhevyh dobavok [Analysis of Russia's place in the world market of food additives]. Vestnik VGUJeiS, 2015, no. 4, pp. 155-164.

29. Tolstova E.G. Sertifikacija sistemy menedzhmenta kachestva kak garantija bezopasnosti produktov pitanija [Certification of quality management system as a guarantee of food safety]. APRIORI. Cerija: Estestvennye i tehnicheskie nauki, 2014, no. 4, p. 9 .

30. Chimonina I.V., Petrosjan S.A. Jekologicheskaja bezopasnost' produktov pitanija. Problemy organizacii tovarosnabzhenija naselenija: tovarovedenie, jekspertiza, tehnologii proizvodstva i prodvizhenija : sb. materialov I Mezhdunar. nauch.praktich. konf. Novosibirsk, 2013, pp. 84-89.

31. Janykova A.D., Filimonova O.G. Cistema zakonodatelstva v oblasti obespechenija kachestva i bezopasnosti produktov pitanija v Rossii. Innovacionnye tehnologii $v$ nauke $i$ obrazovanii : sb. statej pobeditelej III Mezhdunar. nauch.-praktich. konf. Moscow, 2017, pp. 111-113.

\section{Information about the Authors}

Mikhail P. Lyabin, Candidate of Sciences (Chemistry), Associate Professor, Department of Bioengineering and Bioinformatics, Volgograd State University, prosp. Universitetskiy, 100, 400062 Volgograd, Russian Federation, dollaps@mail.ru.

Margarita V. Postnova, Doctor of Sciences (Biology), Senior Researcher, Head of the Department Bioengineering and Bioinformatics, Volgograd State University, prosp. Universitetskiy, 100, 400062 Volgograd, Russian Federation, postnova@volsu.ru.

Alexey I. Bolkunov, Candidate of Sciences (Agriculture), Associate Professor, Department of Bioengineering and Bioinformatics, Volgograd State University, prosp. Universitetskiy, 100, 400062 Volgograd, Russian Federation, ruspole2009@yandex.ru.

\section{Информация об авторах}

Михаил Павлович Лябин, кандидат химических наук, доцент кафедры биоинженерии и биоинформатики, Волгоградский государственный университет, просп. Университетский, 100, 400062 г. Волгоград, Российская Федерация, dollaps@mail.ru.

Маргарита Викторовна Постнова, доктор биологических наук, старший научный сотрудник, заведующий кафедры биоинженерии и биоинформатики, Волгоградский государственный университет, просп. Университетский, 100, 400062 г. Волгоград, Российская Федерация, postnova@volsu.ru.

Алексей Иванович Болкунов, кандидат сельскохозяйственных наук, доцент кафедры биоинженерии и биоинформатики, Волгоградский государственный университет, просп. Университетский, 100, 400062 г. Волгоград, Российская Федерация, ruspole2009@yandex.ru. 